\title{
The ring, the gown, and the apple: the role of magical objects in the Byzantine vernacular romance Kallimachos and Chrysorroi
}

\author{
Rui Carlos Fonseca \\ Universidade de Lisboa \\ rui@campus.ul.pt
}

\begin{abstract}
Magical objects play an important role in the fourteenth-century Byzantine vernacular romance Kallimachos and Chrysorroi, not due to their supernatural powers, but rather in order to make the chivalric status of the romance hero stand out, inasmuch as he does not resort to any of them to achieve his goals.
\end{abstract}

Keywords: Byzantine vernacular romance; Palaeologan fiction; magical objects; supernatural; heroic behaviour

In Greek literary fiction, the hero is often to be found resorting to, or being granted, magical help in order to overcome difficult tasks in a quest or to slay supernatural creatures that the ordinary man cannot face. We see this in the epic warrior in his pursuit for glory and valiant deeds, in the holy man and his fight against evil, as well as in the romance hero during his chivalric adventures and wanderings in search of his beloved princess. Although magic in general, and magical objects in particular, are not recurring motifs in ancient Greek novels, ${ }^{1}$ the topic becomes prominent in Byzantine love fiction of the Palaeologan period. The two verse romances Livistros and Rodamni (mid-thirteenth century) and Kallimachos and Chrysorroi (fourteenth century) are of great importance in this respect.

Palaeologan romances cover a time range from the mid-thirteenth century up to the late fifteenth, and were recited as literary entertainment in front of an elite audience from

1 Heliodorus' Aethiopica is the exception, being the only extant ancient Greek novel where magic is to be found. On this subject, see M. Jones, 'The wisdom of Egypt: Base and heavenly magic in Heliodoros' Aithiopika', Ancient Narrative 4 (2005) 79-98, at 79; C. Cupane, 'Other worlds, other voices: Form and function of the marvelous in Late Byzantine fiction', in P. Roilos (ed.), Medieval Greek Storytelling: Fictionality and Narrative in Byzantium (Wiesbaden 2014) 183-202, at 185-6.

(C) The Author(s), 2020. Published by Cambridge University Press in association with Byzantine and Modern Greek Studies. This is an Open Access article, distributed under the terms of the Creative Commons Attribution licence (http://creativecommons.org/licenses/by/4.0/), which permits unrestricted re-use, distribution, and reproduction in any medium, provided the original work is properly cited.

DOI: $10.1017 /$ byz.2020.4 
Constantinopolitan high society. ${ }^{2}$ These Byzantine vernacular romances (whose authorship is commonly unknown) are deeply engaged with different literary traditions, such as the Hellenistic and Late Antique novel, the twelfth-century Komnenian novel, the fairy-tale tradition, and the chivalric medieval romance from both western and eastern backgrounds. Byzantine writers mimic the standard features of the Hellenistic model, but modify them in order to suit the rhetorical conventions of their own time, thus reviving and reinventing the genre. Due to their heterogeneous influences, the Palaeologan romances present stories of love and adventure set in unknown and exotic lands, far beyond the Mediterranean geography, where the fantastic and the supernatural prevail, the characters finding themselves at strange and marvellous castles, and often being endangered by frightening beasts, magical objects, and deadly witchcraft. ${ }^{3}$

Magic was often perceived in Classical Antiquity as being a derogatory practice, frequently connected with marginalized groups such as barbarian peoples and unregulated domestic rites, mainly performed by women. ${ }^{4}$ In Late Antique and Medieval Byzantium, magic was linked to every kind of unorthodox religious belief and behaviour beyond the authority of Christianity, usually associated with demonic powers and occult sciences. ${ }^{5}$ Magical rituals and incantations required the use of certain special talismanic objects and amulets in specific sacred spaces for different purposes. There are records from the late Byzantine period of a variety of amulets designed for protection, among them circular objects such as rings, stones, and other everyday engraved items. Clothing could also be manufactured in order to ensure someone's safety. Furthermore, a range of tokens, incantations, food, natural elements, and reflective objects could be used for medical care or necromantic activities, or to bring disease, reveal the future, and uncover divine knowledge. ${ }^{6}$ Manifestations of these beliefs, rituals, and their practitioners may be found in various forms throughout

2 On the oral performance of the Palaeologan romances, see C. Cupane, “'Let me tell you a wonderful tale”: Audience and reception of the vernacular romances', in C. Cupane and B. Krönung (eds), Fictional Storytelling in the Medieval Eastern Mediterranean and Beyond (Leiden and Boston 2016) 479-94. See also F. Conca, 'Il romanzo nell'età dei Paleologi: temi e strutture', in C. Roccardo (ed.), Il Romanzo tra Cultura Latina e Cultura Bizantina (Palermo 1986) 33-45, at 36-7 and 45.

3 On the supernatural atmosphere of Kallimachos and Chrysorroi and the Palaeologan romances in general, see C. Cupane, 'In the realm of Eros: The Late Byzantine vernacular romance - original texts', in Fictional Storytelling, 95-126, esp. 96.

4 K. B. Stratton, 'Early Greco-Roman antiquity', in D. J. Collins (ed.), The Cambridge History of Magic and Witchcraft in the West: From Antiquity to the Present (New York 2015) 83-112, esp. 83-6 and 92-4.

5 A. Walker, 'Magic in medieval Byzantium', in The Cambridge History of Magic and Witchcraft 209-34, esp. 210-13; R. P. H. Greenfield, 'A contribution to the study of Palaeologan magic', in H. Maguire (ed.), Byzantine Magic (Washington 1995) 117-53, esp. 118-20.

6 Greenfield divides late Byzantine beliefs and practices concerning magic into three general categories. See 'A contribution to the study of Palaeologan magic', 131-50. 
literary history, from ancient to late medieval times, for instance in epic, drama, hagiography, historiography, and romance. ${ }^{7}$

The Byzantine vernacular romance Kallimachos and Chrysorroi presents three magical objects: a golden ring (which gives its owner the ability to fly), a gown covered in pearls (which heals all wounds), and a witch's apple (which has the power to kill and to bring back to life). Scholars have underplayed the importance of these magical items, considering them as props or lost motifs, as they are mentioned only to be soon forgotten. ${ }^{8}$ As is pointed out by Castillo Ramírez, the hero of this romance, prince Kallimachos, uses none of the magical objects he comes across. Castillo Ramírez argues that the role of magical objects had completely vanished from the romance genre, that they are a stock motif to be employed in literary fiction but serve no purpose in the course of the action being narrated. ${ }^{9}$ Seeking a different approach, I will attempt to show that magical objects do indeed play an essential role within the framework of this Byzantine romance, and that within this same framework they are actually required.

\section{The golden ring}

The story of Kallimachos and Chrysorroi starts with the journey of three royal brothers at their father's demand. After they climb a mountain, rest in a meadow, and pass by a deserted region of cliffs, Kallimachos and his two older brothers finally arrive at a wondrous castle, the golden Dragon's Castle. ${ }^{10}$ Frightened by the terrifying beasts protecting the gates, the older brothers decide to turn away and look for another way forward, but Kallimachos decides to face the unknown dangers of the place. Before the farewell scene, the oldest brother offers Kallimachos, the youngest, a ring with magical properties:

7 On Byzantine magic, see e.g. C. Cupane, 'La magia a Bisanzio nel secolo xiv: Azione e reazione. Dal registro del patriarcato costantinopolitano (1315-1402)', Jahrbuch der Österreichischen Byzantinistik 29 (1980) 237-62; D. F. Abrahamse, 'Magic and sorcery in the hagiography of the middle Byzantine period', Byzantinische Forschungen 8 (1982) 3-18; C. S. Galatariotou, 'Holy women and witches: Aspects of Byzantine conceptions of gender', Byzantine and Modern Greek Studies 9 (1984) 55-94; R. P. H. Greenfield, Traditions of Belief in Late Byzantine Demonology (Amsterdam 1988); H. Maguire (ed.), Byzantine Magic (Washington 1995); A. J. Goldwyn, 'Towards a Byzantine ecocriticism: Witches and nature control in the medieval Greek romance', Byzantine and Modern Greek Studies 39 (2015) 66-84; A. J. Goldwyn, Byzantine Ecocriticism: Woman, Nature, and Power in the Medieval Greek Romance (Cham, Switzerland 2018) Chap. 4.

8 C. García Gual, 'Introducción', in Calímaco y Crisórroe (Madrid 1982) 9-48, at 24; C. Cupane, Romanzi Cavallereschi Bizantini (Torino 1995) 74, n. 14, and 152, n. 104.

9 E. Castillo Ramírez, 'El Calímaco y Crisórroe a la luz del análisis del cuento de V. Propp', Erytheia 21 (2000) 73-118, at 82 and 114.

10 On the castle in late Byzantine romance, see C. Cupane, 'Il motivo del castello nella narrativa tardo-byzantina', Jahrbuch der Österreichischen Byzantinistik 27 (1978) 229-67, esp. 236-41 (on the Dragon's Castle). 


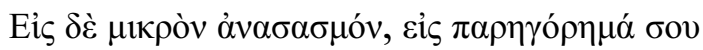

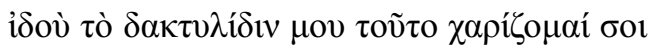

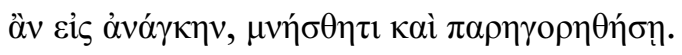

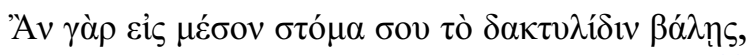

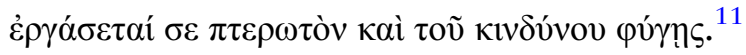

'But as some small relief and comfort, I give you this ring of mine. If you are in peril remember it and you will find solace. If you put it into your mouth it will give you wings and you will escape the danger. ${ }^{, 12}$

This offering scene takes place in front of the mighty Dragon's Castle, whose walls are said to be so high that they reach the heavens. ${ }^{13}$ References to the boundless height of this wondrous castle are recurrent throughout the narrative. All the male characters who stand before it - beyond the three brothers, these include the foreign king, his lords, and armies - are frightened by its striking dimensions and strength. The lords gathered at the king's council 'All considered the castle to be impregnable in battle when they saw its supernatural walls and battlements; it could not be taken; its strength and its size rendered it completely invulnerable to ruses and impossible to

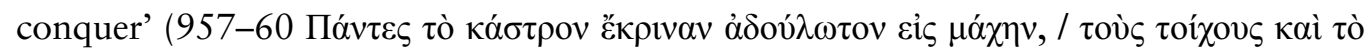

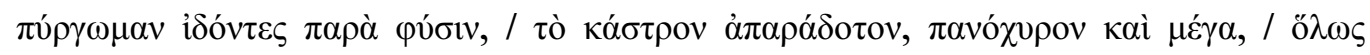

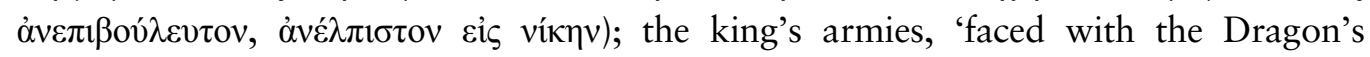
Castle, serpents for adversaries, and walls of boundless height which were not of

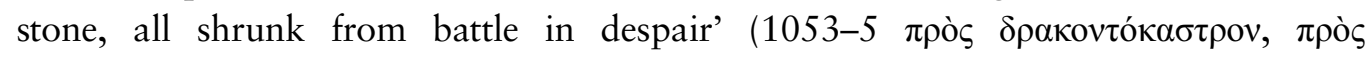

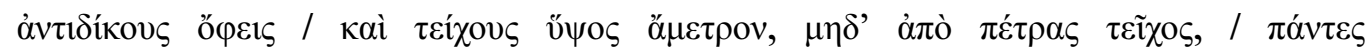

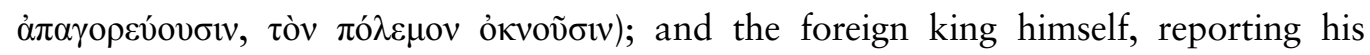
pangs of love to the old woman, tells her 'why he went to the Dragon's Castle; how he saw the shining gold, the gleaming precious stones, the silver and pearls, the castle wall

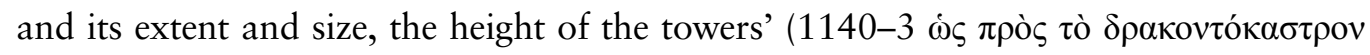

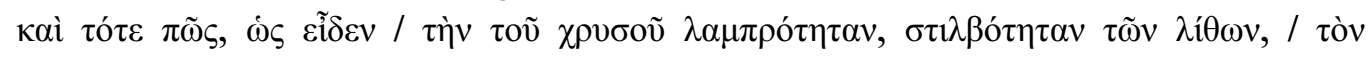

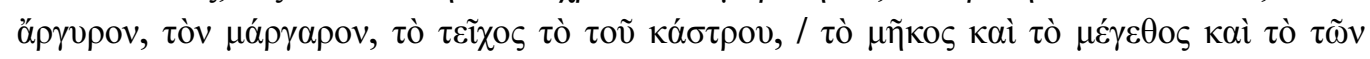

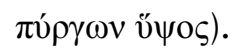

Kallimachos could make use of the magical power of the ring if he wanted, because wings are clearly a useful resource in order to pass over walls that reach to the heavens. Herbert Hunger states that in a typical fairy-tale scenario the hero would be expected to resort to wings or an invisible helmet in order to enter a castle guarded by frightful

11 Text M. Pichard, Le Roman de Callimaque et de Chrysorrboé (Paris 1956), henceforth KóC, 261-5.

12 Transl. G. Betts, Three Medieval Greek Romances (New York and London 1995) 37-87.

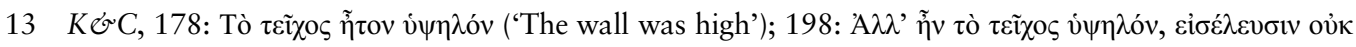

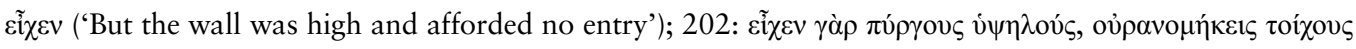
('The castle had lofty towers and walls that reached to the heavens'). 
gatekeepers. ${ }^{14}$ Against all expectations, the narrator refuses to grant Kallimachos use of these supernatural powers. Instead, the young man proves his heroic valour with his spear. He uses it to jump manfully over the walls and enter the castle, in the same way Achilles does in The Tale of Achilles. ${ }^{15}$

In this way, Kallimachos overcomes the immeasurable height of the walls and escapes the close surveillance of the dragons at the gates. Kallimachos is the only character to accomplish this impossible task of finding a breach in the walls of the castle and getting inside. In not allowing his hero to use the magical ring, the narrator illustrates Kallimachos' heroic excellence, as he accomplishes an unparalleled achievement which others find impossible. Afterwards, Kallimachos slays the lord of the castle, a man-eating dragon, and also slays the magic dragon summoned by the old witch. However, in his very first chivalric deed in the face of danger, he overcomes the ever-watchful dragons at the gates by himself, with no need of his brothers' assistance and without resorting to any supernatural power. In his first victory, Kallimachos acts alone, manifesting a truly heroic temperament.

The magic golden ring might have been used at another moment in this romance. After slaying the lord of the castle and saving the princess, Kallimachos enjoys an anticipated happy ending, living in the Dragon's Castle with his much-beloved Chrysorroi. Later, however, the girl is kidnapped by a foreign king, and the hero, after being killed and revived by the magic power of the golden apple, departs in search of her. ${ }^{16}$ When Kallimachos finally learns her whereabouts, he curses nature for not providing him with wings that would enable him to reach his destination faster. During his wanderings, we are told that Kallimachos had lost his magic ring around the time Chrysorroi was taken from the Dragon's Castle and he himself had died. ${ }^{17}$ Thus, unable to use the magic ring for his own benefit, the young man complies with the rules set out for the hero of Greek novels: he must endure the hardships of Fortune during his search. Kallimachos reaches the palace of the foreign king only after much effort and wandering. In this way, he shows his endurance and the strength of his love for Chrysorroi by facing hard situations.

According to the generic requirements of the Greek novel, Fortune strikes the young lovers with many sorrows. Before they may live happily ever after, the couple must face a set of perils, hardships, and temptations which put their love to the test. Only after much

14 H. Hunger, 'Un roman byzantin et son atmosphère: Callimaque et Chrysorrhoè', Travaux et Mémoires 3 (1968) 405-22, at 411.

15 KÆC, 271-7. Cf. The Tale of Achilles 1071-4. See D. C. Hesseling (ed.), L’Achilléide Byzantine (Amsterdam 1919) 70; J. A. Moreno Jurado (ed. and transl.), Aquileida: poema anónimo bizantino (Madrid 1994) 94-7.

16 For a brief analysis of the oneiric appearance of Fortune to Kallimachos' older brothers, which leads to

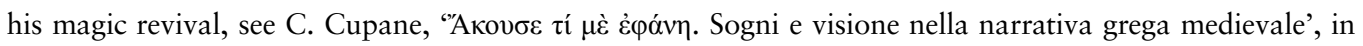
G. Lalomia and A. Pioletti (eds), Temi e motivi epico-cavallereschi fra Oriente e Occidente. Medioevo Romanzo e Orientale (Soveria Mannelli 2010) 91-114, at 99.

$17 \mathrm{~K} \mathrm{C}, 1548-52$. 
sorrow and distress may they enjoy full happiness. ${ }^{18}$ Kallimachos is thus prevented from resorting to the supernatural powers of the golden ring, so that his heroic value (as an epic and romance hero) may stand out. As Lars Nørgaard states regarding the epic character of the Byzantine romances, 'it is the test that reveals the true character of the protagonists. $^{19}$

The golden ring has a non-magical counterpart: the ring of Chrysorroi's mother, which is used as a recognition token between the young lovers. This family ring is first mentioned at the palace of the foreign king $(K \mho C, 1719-24)$ when Kallimachos, disguised as the gardener's helper, wishes to reveal his identity to his beloved, who is once again imprisoned, although this time she holds the status of queen. Only in this second half of the romance, at the palace of the foreign king, do we learn that Kallimachos had received this ring from Chrysorroi in the bath scene at the Dragon's Castle, even though at that moment there was no mention of this second ring. The late revelation of the origins of this second ring raises some interesting issues, if we bear in mind the novelistic tradition in both the Hellenistic and Byzantine periods.

In Chariton's novel, Callirhoe has a ring bearing Chaereas' portrait (I, 13-14). ${ }^{20}$

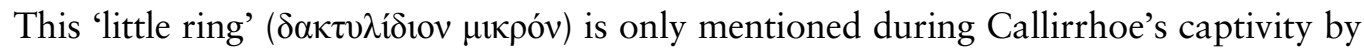
the pirates. No other information is provided regarding the circumstances in which she had received it: whether it is a courtship present, a wedding gift, or a funeral offering. On the other hand, in Digenis Akritis (IV, 364), ${ }^{21}$ the hero receives a ring (iò $\delta \alpha \kappa \tau v \lambda i \delta v v)$ as a token of love from his beloved, but it is never mentioned again in this 'epic' or 'proto-romance', according to Beaton's classification. ${ }^{22}$ Neither of these non-magical rings plays an important role in its narrative, but instead merely an incidental one. In both cases, the background story of each ring is only partially told: in Chariton's romance, we are told that the ring is in the possession of Callirhoe, and in Digenis Akritis we witness the moment when the hero receives the ring.

The exchange of rings between lovers is also a common motif in Byzantine vernacular romance. In Livistros and Rodamni, ${ }^{23}$ the hero offers the girl his ring with a love letter, and in return the girl offers him her ring with a love letter of her own. ${ }^{24}$

18 On the presence of Fortune in Kallimachos and Chrysorroi, see the comparative study of G. Van Steen, 'Destined to be? Tyche in Chariton's Chaereas and Callirhoe and in the Byzantine romance of Kallimachos and Chrysorroi', L'Antiquité Classique 67 (1998) 203-11, esp. 207-11.

19 L. Nørgaard, 'Byzantine romance - Some remarks on the coherence of motives', Classica et Mediaevalia 40 (1989) 271-94, at 286.

20 Chariton, De Callirhoe narrationes amatoriae, ed. B. P. Reardon (Munich and Leipzig 2004).

21 E. Jeffreys (ed. and transl.), Digenis Akritis: The Grottaferrata and Escorial Versions (Cambridge 1998).

22 R. Beaton, The Medieval Greek Romance, $2^{\text {nd }}$ ed. (London and New York 1996) 31-2.

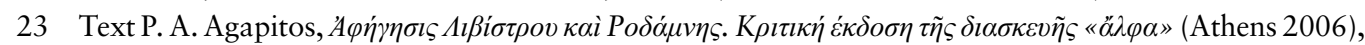
henceforth L\&R. Transl. Betts, Three Medieval Greek Romances, 95-185.

$24 L \mho R, 1963-75$ and 1989-2014. Livistros' ring has 'a pure ruby. On the side was iron and, on the outside, lodestone. Between, to bind the iron and lodestone, was pure gold, refined to the utmost'

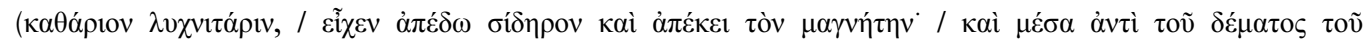

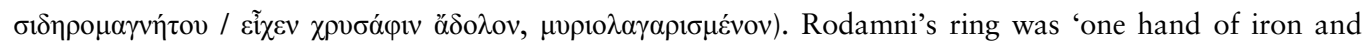


Rodamni later gives the ring she received from Livistros to Klitovon, as a recognition token for Livistros ( $L \mho R, 3834-7)$. If we follow the pattern of this Byzantine model, we may ask: if Kallimachos receives Chrysorroi's family ring, why doesn't he give her his own in return, the one he had previously received from his older brother? In the bath scene in the Dragon's Castle, the hero has not yet lost it. If Chrysorroi had the magical ring in her possession, with the power of flight she could easily escape her captivity in her kidnapper's palace, and Kallimachos would not have the opportunity to save her.

Another hypothesis can be entertained: the two rings of this Byzantine romance could easily be one, used at different stages, if the narrator so wished. The stories of Kallimachos' magical ring and Chrysorroi's family ring complement each other: regarding the first, we are told of it being offered by a family member but not of its actual use; regarding the second, we are only told of its function as a recognition token, but not of its initial offering by a family member. In Heliodorus' Aethiopica ${ }^{25}$ we find a significant precedent. Charikleia's ring was inherited from her mother (IV, 8) and plays the double function of recognition token $(\mathrm{V}, 5)$ and magical object in times of great danger: it repels fire and bestows upon its wearer invulnerability to fire; more importantly, the ring saves Charikleia from certain death (VIII, 9 and 11). ${ }^{26}$

The narrator of Kallimachos and Chrysorroi could easily have used just one ring both in order to help the hero fulfil his difficult tasks and for the subsequent recognition between the two young lovers. However, the narrator prevents the couple from resorting to supernatural powers. Instead, he prefers that they suffer Fortune's ordeals and overcome their obstacles without magic. That is the reason why Kallimachos must necessarily lose his brother's ring: because he has to endure the hardships of his wanderings. In making his hero lose the magic ring, the narrator is obliged to announce a second ring for the recognition scene that will lead to the couple's reunion.

\section{The gown covered in pearls}

During Kallimachos' wanderings in search of Chrysorroi, we learn that the hero had previously found a shining gown covered in pearls that has healing properties. From the moment Kallimachos enters the Dragon's Castle to the moment he departs to look for Chrysorroi, we find no mention of the healing gown. Its appearance is delayed for a subsequent scene of the narrative:

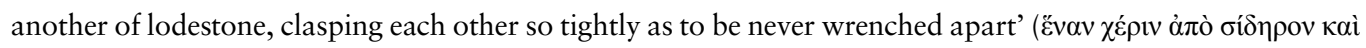

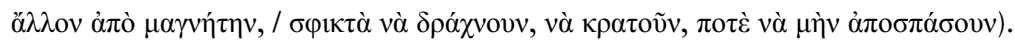

25 Héliodore, Les Éthiopiques (Théagène et Chariclée), eds R. M. Rattenbury and T. W. Lumb, transl. J. Maillon, 3 vols. (Paris 1943-1960). English transl. J. R. Morgan, An Ethiopian Story, in B. P. Reardon (ed.), Collected Ancient Greek Novels (Berkeley, Los Angeles and London 2008) 349-588.

26 On Charikleia's ring as being an amuletic recognition token, see Jones, 'The wisdom of Egypt', 91-3. 


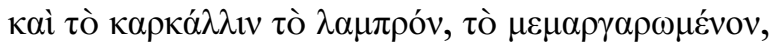

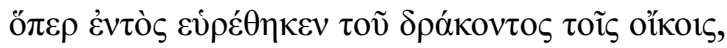

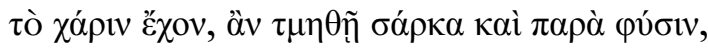

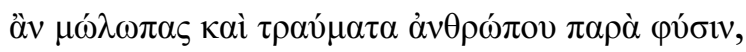

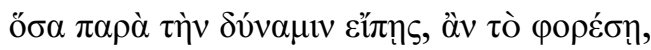

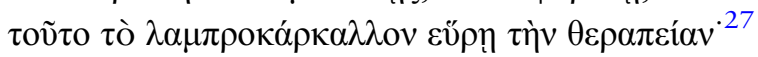

... the shining gown covered with pearls which was inside the dragon's abode and which had the virtue of curing its wearer of even supernatural cuts, of supernatural bruises and wounds, everything that one would think beyond the power <of medicine> ...

When the hero finds Chrysorroi imprisoned in the wondrous golden castle by a man-eating dragon, she is first presented as having been tortured and whipped. Her weak and malnourished body is entirely covered in wounds and bruises. After slaying the sleeping dragon, following the girl's instructions, the young hero takes care of the princess. In this first encounter, when they tell their stories to each other, there is no mention of any healing gown. However, the clothes of Chrysorroi's parents (kept by the dragon inside his chamber) stand out. Among these clothes the hero finds a

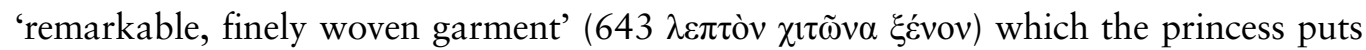
on after being rescued. After Chrysorroi has been kidnapped and Kallimachos' older brothers save him from his temporary death, Kallimachos tells them what has happened in the Dragon's Castle since his arrival, and in his summary he mentions

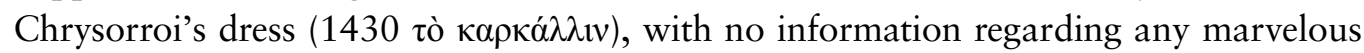
features or magic properties.

The question we may then ask becomes obvious: are the garment of Chrysorroi's parents and the healing gown one and the same? The garment was the first piece of clothing Chrysorroi put on after she was rescued, and it was from that moment that her body started healing and regained its former beauty. The narrator does not actually clarify whether it is the same dress or two different dresses. ${ }^{28}$ What we see is, in fact, a strong emphasis upon the role that Kallimachos plays in Chrysorroi's recovery: 'Kallimachos replied, "What are you saying? I alone shall clean your

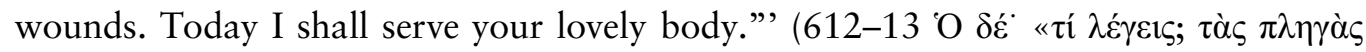

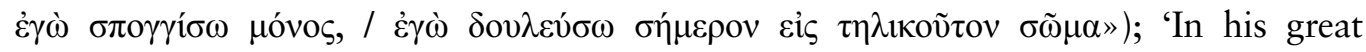
happiness he embraced the maiden and when he had covered her bruises with kisses

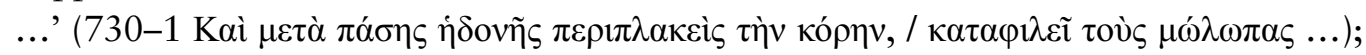
'how Kallimachos caressed the maiden's wounds and from touching her bruises he

28 The Greek word employed for the magic gown in line 1556 is карка́ $\lambda \lambda \iota v$, the same as for Chrysorroi's dress, previously referred to by Kallimachos in line 1430. The garment belonging to Chrysorroi's parents found by the hero in the dragon's chamber is first presented in line 643 as $\chi \imath \tau \tilde{\omega} v \alpha$. 
received an inexpressible freshness and from her kisses a dewy sweetness' (775-8 ö $\pi \omega \varsigma \tau \tilde{\eta} \varsigma$

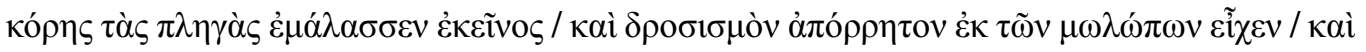

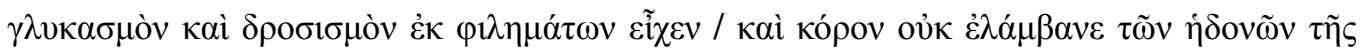

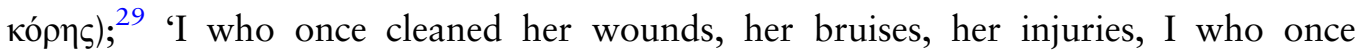

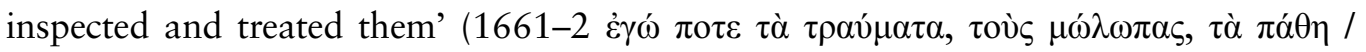

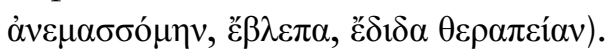

The narrator does not make any connection between the two dresses; instead each one is mentioned separately. He rather emphasizes the idea that Kallimachos was the main force responsible for Chrysorroi's recovery, with his kisses, caresses, and devotion. In this Byzantine vernacular romance, we read about the healing power of first love. Like the golden ring, the magical gown also has a non-magical counterpart, and this common item plays a more prominent role in the narrative, as it marks the birth of passion between the hero and the princess. It is only after Chrysorroi puts on the garment that she speaks of herself, and the two engage in a more intimate relationship. As we have already seen regarding the magical ring, the healing gown's importance is diminished, less than that of the common dress and the romantic behaviour of the hero. Once again, it is through Kallimachos' own actions (entirely free of any magical help) that he accomplished this new task, rescuing the princess from the physical torture inflicted by the dragon.

\section{The golden apple}

The golden apple is the third magical object of this Byzantine vernacular romance and is a product of the witch's magic. The witch in Kallimachos and Chrysorroi is first presented as being an evil old woman, crafty and of a demonic nature, learned in astrology, and able to master spirits by magical arts $(K \mho C, 1065-7)$. Hearing about the foreign king's illness, the witch goes to his palace where, despite her miserable appearance and wretched clothes, she makes herself known at the gates as having an exceptional talent for healing like no other in the whole world. Once in the king's chamber, the witch performs her first enchantment, saving the foreign king from a heart attack by

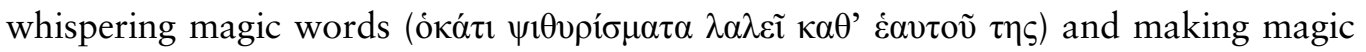

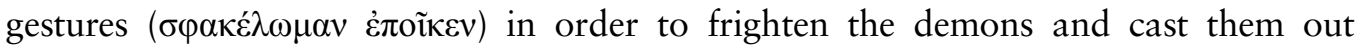
$(K \mho C, 1160-8)$. After the king's recovery, she puts herself at his service, promising to get the lady from the Dragon's Castle for him. She then enchants a golden apple with a double spell:

29 On the erotic bath described in 754-806, Agapitos states that 'the bath is invested with magical powers as it transforms Kallimachos and Chrysorrhoe and makes them more beautiful than they were before (792-6).' P. A. Agapitos, 'The erotic bath in the Byzantine vernacular romance Kallimachos and Chrysorrhoe', Classica et Mediaevalia 41 (1990) 257-73, at 267. The bath scene is also discussed by Garland, who emphasizes Kallimachos' priority of personally doctoring Chrysorroi's injuries and kissing her wounds. L. Garland, “"Be amorous, but be chaste...": Sexual morality in Byzantine learned and vernacular romance', Byzantine and Modern Greek Studies 14 (1990) 62-120, esp. 113-15. 


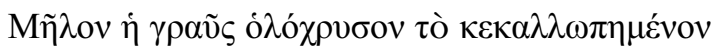

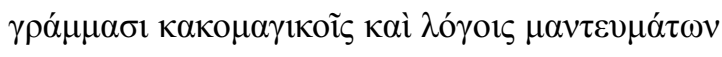

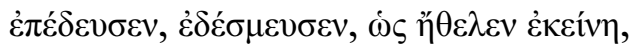

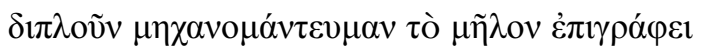

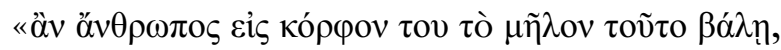

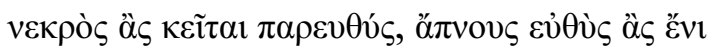

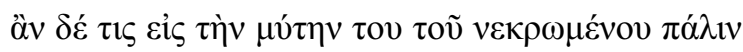

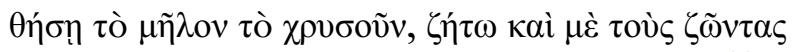

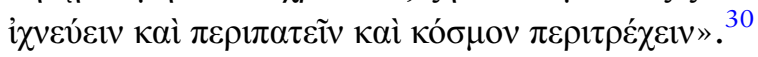

Using letters of evil magic, and incantations, the old woman placed the charm she desired on a beautifully made apple of pure gold. She wrote a double spell upon it: 'If anyone puts this apple into his bosom he will straightway fall dead; his breath will fail immediately. But if this golden apple is held to the nose of the dead person, he will come to life, go, walk, and traverse the world with the living.'

Once the magic procedure is complete, the witch takes three months to reach the Dragon's Castle in the company of the foreign king and an army of hundred men. After setting up camp, she hides herself on the island, where she stays alone among demons, and takes another three days to prepare a third and final spell $(K \& C, 1196-$ 201 and 1215-50). ${ }^{31}$ Finally, the day comes when the young Kallimachos and his beloved Chrysorroi hear a strange voice that fills them with anguish, and a fearsome dragon emerges from the forest. ${ }^{32}$ The hero immediately leaves the castle, runs towards the dragon, attacks, and beheads it. However, the creature is not a real dragon, but rather another magic scheme concocted by the evil witch (K\&C, 1292), whose main goal was simply to draw the hero outside of the castle's walls. The old woman,

$30 \mathrm{~K} \mathrm{C}, 1206-14$. The double spell engraved upon the witch's golden apple is again mentioned only partially in Kallimachos' resurrection scene (1405-11), very briefly during Kallimachos' search for the abducted Chrysorroi (1562-3), and again in full when Kallimachos makes his final speech at the trial (2551-9).

31 See Greenfield, Traditions of Belief, Part II, Chap. 6, esp. 250 (on Kallimachos' witch and her demonic nature), 250-1 (on Livistros' witch), 253 (on the relationship of reciprocity between demons and those who summon them), 257-60 (on the most favorable time and place to summon demons and secure their co-operation).

32 The three dragons in Kallimachos and Chrysorroi differ in terms of their physical features. The gatekeeper-dragons stand out for their constant surveillance: they never sleep, and are always watching, but they do not notice Kallimachos entering the castle. The dragon who keeps Chrysorroi captive stands out for his stomach, his devouring of large portions of food and drink; nonetheless he is slain in his sleep after eating too much, and his body is cut in two. The dragon conjured by the witch makes himself known at first by roaring, and thereafter he is beheaded by Kallimachos. On this subject, see R. C. Fonseca, 'A excelência heróica na luta contra o dragão: um motivo épico no romance bizantino Calímaco e Crisórroe', eClassica 1 (2015) 82-90, esp. 88-9. 
presenting herself as a victim of the newly beheaded dragon, gives Kallimachos the golden apple as a reward for his heroic behaviour. He holds it in his hand, admires its beauty and, ignorant of the true identity of the old woman and the magic nature of the apple, slips it inside his shirt, and falls dead on the spot. This is how the foreign king manages to abduct the princess, with whom he has fallen in love, and take her to his palace. ${ }^{33}$

The witch's apple receives a much more developed story than the ring and the gown, and it actually fulfils its magical role. We learn about this apple at the moment of its creation by the old witch; we are told of its double power, the offering to Kallimachos, and finally we see its effects at work: the golden apple causes the hero's death and brings him back to life. Only its final destiny is not revealed. We assume that the last characters to have taken possession of the apple (Kallimachos' older brothers) kept it for themselves. Kallimachos suffers the harmful effects of accepting a magical item, even though he had no idea of its true, magical nature. Be that as it may, the fact is that the golden apple's purpose is achieved: it causes Kallimachos' death, Chrysorroi's abduction, and is therefore the main cause for the young couple's separation. ${ }^{34}$

Kallimachos is not the only character to fall victim to magic. In fact, all characters involved in the episode of the apple are punished in one way or another. The foreign king engages the services of the old witch and, at first, the enchanted apple grants him what he desires most, the fair lady of the Dragon's Castle, but then it deprives him of his prize, since at the end of the narrative the young lovers are inevitably reunited. Kallimachos is the prime target of the apple. It was made for him: first it brings him death, but then it brings him back to life. The effects of the golden apple are equally balanced both for the hero and his antagonist, but in opposite directions: Kallimachos loses his life and regains it with the help of his older brothers; the foreign king succeeds in capturing the fair lady with the help of the old witch, but later loses her. ${ }^{35}$ Finally, the old witch, who summons 'letters of evil magic, and incantations' in order to create the apple with the twofold power of life and death, suffers its double effects

33 The scene of the enchanted golden apple's offering includes a superb description of the witch's wicked demonic nature ( $K \& \mathrm{C}, 1304-8)$.

34 On the symbolic role of the apple in Classical and Byzantine literature, see three works of A. R. Littlewood: 'The symbolism of the apple in Greek and Roman literature', Harvard Studies in Classical Philology 72 (1968) 147-81; 'The symbolism of the apple in Byzantine literature', Jahrbuch der Österreichischen Byzantinistik 23 (1974) 33-59, esp. 51-2 (on Kallimachos' enchanted apple); and 'The erotic symbolism of the apple in Late Byzantine and meta-Byzantine demotic literature', Byzantine and Modern Greek Studies 17 (1993) 83-103. Book 3 of Aethiopica also has a scene where apples are vaguely, but possibly, associated with magic, in particular with love spells. See Jones, 'The wisdom of Egypt', 87.

35 On the narrative structure of Kallimachos and Chrysorroi and the storylines of the hero and the rival, see R. C. Fonseca, 'The hero, the rival, and the dragon: The tripartite structure of Kallimachos and Chrysorrhoe', Parekbolai 7 (2017) 135-49, esp. 141-9. For a broader analysis of vernacular romances' overall narrative structure, see F. Conca, 'Il romanzo nell'età dei Paleologi', 33-45; Beaton, The Medieval Greek Romance, 117-34; P. A. Agapitos, Narrative Structure in the Byzantine Vernacular Romances: A Textual and Literary Study of Kallimachos, Belthandros and Libistros (Munich 1991); P. A. Agapitos, 'Genre, structure, and poetics in the Byzantine vernacular romances of love', Symbolae Osloenses 79 (2004) 7-101. 
as well: she wins royal thanks with Kallimachos' death and Chrysorroi's abduction, but is thrown into the fire by royal decree when the king loses his queen. This only happens because of the magical resurrection of Kallimachos.

The death of the witch is already an expected motif in later Greek literary fiction. In Aethiopica and Livistros and Rodamni, witches engage with supernatural forces and die: in the former, an old woman of Bessa in Egypt who reanimates the corpse of her dead son, killed in battle, runs through a field of dead bodies, accidently falls on a broken spear and dies (VI, 14-15), while in the latter story a witch who controls demons is slain by the hero at his beloved's command ( $L \mathcal{\mho} R, 4060-8)$. In both these love narratives the witch's death is required as punishment for her use of black magic. The witch dies because she deals with forces that are beyond the human world, transgressing the boundaries separating the realm of the living from the realm of the dead. In Livistros and Rodamni, as well, the hero suffers a temporary death caused by the magic arts of a witch, who commands a demon to take the shape of a ring. This object is first presented as a precious stone 'in the form of a ring, uncut, natural, red as fire' ( $\dot{\omega} \varsigma \delta \alpha \kappa \tau \nu \lambda i \delta$ iv, I

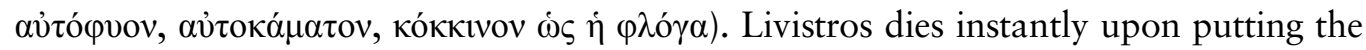
enchanted ring on his finger $(L \& R, 2667-82) .{ }^{36}$

According to the dead soldier's prophecy in Aethiopica, the wicked woman dies because, in performing necromantic rituals, she contravenes the laws of man's nature, affronts the ordinances of destiny, and uses the black arts to move the immovable (VI, 15). ${ }^{37}$ It is for these same reasons that the old witch of Kallimachos and Chrysorroi must die. The king who first requested her services later orders her death because she gave the apple the double power of death and life $(K \mho C, 2578-84){ }^{38}$

36 The enchanted ring of the witch in Livistros plays the same exact role as the magic golden apple produced by the witch in Kallimachos. Both are specifically designed to tear the lovers apart, by killing the male characters and abducting the princesses. When the ring is removed from his finger, Livistros immediately returns to life, as does Kallimachos when the apple is taken away from him.

37 On the reanimation-necromancy scene and the witch's death at the end of Aethiopica's Book 6, see D. Ogden, Magic, Witchcraft, and Ghosts in the Greek and Roman Worlds: A Sourcebook (Oxford and New York 2002) 201; D. Ogden, Greek and Roman Necromancy (Princeton and Oxford 2004) 147 and 265; Jones, 'The wisdom of Egypt', 83-4; C. Ruiz-Montero, 'Magic in the ancient novel', in M. Paschalis, S. Frangoulidis, S. Harrison, and M. Zimmerman (eds), The Greek and the Roman Novel: Parallel Readings (Groningen 2007) 38-56, at 42-3; Cupane, 'Other worlds, other voices', 185-6; N. W. Slater, 'Posthumous parleys: Chatting up the dead in ancient novels', in The Greek and the Roman Novel, 57-69, at 61. Cf. Aethiopica III, 16, where Kalarisis draws a distinction between base wisdom (of low rank) and true wisdom, the former usually bringing its practitioners' own downfall.

38 Goldwyn sees the witch's death by the king's decree at the end of Kallimachos and Chrysorroi as 'inexplicably strange and cruel,' as it seems unlikely that the foreign king would want to condemn the old woman only because she gave the apple a double power. See Goldwyn, 'Towards a Byzantine ecocriticism', 82; and Goldwyn, Byzantine Ecocriticism, 152-3. García Gual argues that the witch's death compensates the couple's sufferings throughout the story, and notes that it is actually expected in the fairy-tale tradition; nevertheless, he finds it odd that the witch has no magic trick with which to escape fire. García Gual, 'Introducción', 38-9. On Kallimachos' witch portrayed as a fairy-tale character, see Hunger, 'Un roman byzantin et son atmosphère', 408 . 
Dealing with magic, namely with magic that transgresses unnatural boundaries, is an unacceptable act that must be punished with death.

If we bear in mind the mythological and the literary Greek traditions, we note the same belief regarding the natural order designed for the living and the dead. Asclepius, the hero and god of medicine, healed the sick and found a way to revive the dead; Zeus struck him with a thunderbolt, fearing that, if he continued his miraculous healing, Asclepius could reverse the order of the world. ${ }^{39}$ In Homer's Odyssey, Helios Hyperion demands vengeance on Odysseus' comrades for killing his sacred cattle, and threatens to shine over the dead down in Hades, thus causing a disaster of catastrophic proportions, if Zeus does not bring immediate justice against the insolent men (Od. 12.377-83). These two stories, among many others that could be drawn from the ancient traditions, show that the dwelling place of the living and that of the dead are two opposed worlds, each playing a specific role within a balanced cosmic order. The descent from one to the other is a one-way trip, and a return is not expected, and would therefore be an act magically accomplished against Nature's control.

In Heliodorus' Aethiopica, Charikleia hears the prophecy told by the reanimated corpse of the dead soldier about her glorious royal future (VI, 15). In Livistros and Rodamni, the hero accepts the witch's magical help in order to recover his beloved from his rival's domain. Livistros and his friend Klitovon cross the sea all the way to Egypt, riding flying horses provided by the old woman $(L \& R, 3101-86) .{ }^{40}$ By contrast, in Kallimachos and Chrysorroi, the young couple rejects the use of magical objects, because magic always comes with a deadly price, as the enchanted apple shows. Instead of magical objects, the hero and his princess choose to use ordinary, non-magical items.

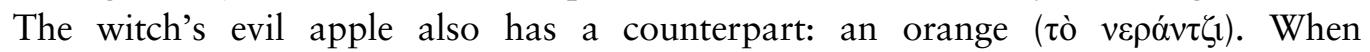
Kallimachos finds Chrysorroi in the palace of the foreign king, he ties the princess' family ring to the fruit of the orange tree, using it as a recognition token $(K \mho C, 1739-$ 46, 1759-63). Thus, while the enchanted apple tears them apart, the orange tree in the royal garden brings them back together. Therefore, the young couple has no need of any supernatural power for their reunion, just an element provided by Nature.

39 On the Asclepius myth regarding his remarkable healing skills, see e.g. Pindar, Pythian 3; Pausanias, Description of Greece, 2.26-7; Apollodorus, Bibliotheca, 3.10.3-4; Virgil, Aeneid, 7.765-73; Propertius, Elegies, 2.1.57-62; Ovid, Metamorphoses, 2.633-54, and Fasti, 6.743-62. For a full survey on Asclepius, his legend, descendants, deification, contribution to medicine, cult, images, and sanctuaries, see E. J. Edelstein and L. Edelstein, Asclepius: A Collection and Interpretation of the Testimonies (Salem, NH 1988), esp. I 37-48 (for testimonia on Asclepius' mythical reviving and healing) and I 53-6 (for testimonia on Asclepius' death).

40 For an analysis of Livistros and Klitovon's journey across the sea on flying horses, see C. Cupane, 'Itinerari magici: il viaggio del cavallo volante', in M. Cassarino (ed.), Sulle orme di Sharazàd: Le «Mille e una notte» fra Oriente e Occidente. Medioevo Romanzo e Orientale (Soveria Mannelli 2009) 61-79. On the magical contexts in which Livistros and Rodamni's separation and reunion are set, see Cupane, 'In the realm of eros', 109. On the voyage motif, on both real and magic levels, in Palaeologan romances, see F. R. Nervo, 'Il motivo del viaggio e il cronòtopo del romanzo cavalleresco bizantino', in Temi e motivi epico-cavallereschi fra Oriente e Occidente, 261-73. 


\section{The 'phenomenon of triplication'}

In Kallimachos and Chrysorroi, two of the three magical objects do not fulfil their role. That does not mean that their presence in the romance is pointless. The presence of these unused magical items is calculated and has a very important role within the overall structure of the narrative. Castillo Ramírez has already noted that the number three is purely conventional within the fairy-tale tradition. ${ }^{41}$ She also refers to the phenomenon of triplication. In fact, if we look closely, we notice that the three magical objects in Kallimachos and Chrysorroi fit an overall narrative structure that, in many aspects, is organized into triads:

\section{Characters}

Three brothers: Nikokles, Xanthippos, Kallimachos.

Three suitors: the man-eating dragon, Kallimachos, the foreign king.

Three horsemen circle the Dragon's Castle with the foreign king.

Three eunuchs are in the service of the foreign king.

\section{Time}

Three months (approximately): the three brothers travel to the summit of the mountain.

Three months: the old witch and the king and his troops travel to the Dragon's Castle. Three days: the old witch prepares her magic against the young couple.

Three days: the eunuchs' ruse deceives the fair lady.

\section{Space}

Three places the brothers come across: the mountain, the meadow, the region of the cliffs.

Three castles: the castle of Kallimachos' father, the Dragon's Castle, the king's palace.

Three gardens of the Dragon's Castle: the large courtyard garden, the flower garden hanging over the side of the pool, the fair island outside the castle's walls. Three main spaces in the king's palace: the king's bedroom, the garden, the pavilion. ${ }^{42}$

\section{Castillo Ramírez, 'El Calímaco y Crisórroe', 89.}

42 See Agapitos' Narrative Structure for Kallimachos and Chrysorroi's narrative time (228-30 and 240-3) and narrative space (276-7 and 282-97). On Byzantine gardens, see A. R. Littlewood, 'Romantic paradises: The rôle of the garden in the Byzantine romance', Byzantine and Modern Greek Studies 5 (1979) 95-114; Ch. Barber, 'Reading the garden in Byzantium: Nature and sexuality', Byzantine and Modern Greek Studies 16 (1992) 1-19; K. Stewart, 'The image of the heroine in three Palaeologan romances', The Byzantinist 2 (2012) 10-11. On the heroine's portrayal in dendromorphic and anthomorphic imagery in Byzantine Komnenian novels, see I. Nilsson, 'Romantic love in rhetorical guise: The Byzantine revival of the twelfth century’, in Fictional Storytelling, 39-66, esp. 45-6; Goldwyn, Byzantine Ecocriticism, Chap. 3. 
In the same way, it is also possible to organize the magical elements into triads:

Three dragons: the gatekeepers, the man-eating dragon, the dragon's witch. Three enchantments of the witch: the king's recovery, the dragon, the apple. Three magical objects: the ring, the gown, the apple.

Three recitations (full or partial) of the apple's spell by three different characters.

The magical objects are mentioned in this romance, but are not meant to be used, but instead to be put aside. Their main function lies in the absence of their use qua magic by the young couple. As we have seen, magic only brings them misfortune. Furthermore, the non-use of magical items enhances the epic status of the main characters, especially the heroic behaviour of Kallimachos. He manages without help to jump over inaccessible walls, to heal Chrysorroi's wounds and the bruises inflicted by the dragon, to endure the hardships of his wanderings, and to find a recognition token in Nature. The narrator provides magical items that could allow the hero to achieve these same deeds more easily, but does not let him use them, so the hero must adopt non-magical procedures and rely upon his own resources. In this way, the magical objects, apparently forgotten within the narrative, bring out Kallimachos' heroic performance. ${ }^{43}$

Rui Carlos Fonseca holds a Ph.D. in ancient Greek literature, awarded in 2013. His research interests focus on Homeric poetry, epic parodies, the Palaiologan romance and reception studies. Among other publications, he is the author of Epopeia e Paródia na Literatura Grega Antiga (2018). Currently he is a postdoctoral research fellow at the Centre for Classical Studies, University of Lisbon, working on Byzantine vernacular romance.

43 This article was written as part of my postdoctoral research on Byzantine romance, funded by the FCT Fundação para a Ciência e a Tecnologia (SFRH/BPD/99542/2014). This article is also supported by the Portuguese Foundation for Science and Technology (Grant UIDB/00019/2020). 